\title{
Çeşitli Zekâ Düzeylerine Sahip İlkokul Öğrencilerinin Davranış Problemleri ile Aile İşlevleri Arasındaki İlişskinin İncelenmesi*
}

\author{
A Research on the Relationship Between Parenting Functions and Various \\ Behaviour Problems of Primary School Children Having Different Levels Of IQA.
}

Nilgün CANEL $^{* *}$
H. Pınar ÖZDEMÍR-KEMAHLI

Öz

Bu çalışmanın amacı, üstün zekâlı öğrencilerin, zihinsel engelli öğrencilerin ve normal zekâya sahip öğrencilerin davranış problemleri ile aile işlevleri arasındaki ilişkinin incelenmesidir. Ayrıca aile işlevlerinin sağlıklı olup olmayışı ve öğrencilerin davranış problemlerine göre grupların farklılaşıp farklılaşmadığı da karşılaştırılmıştır. Araştırma ilişkisel tarama modeline dayalı betimsel bir çalışmadır. Araştırmaya; İstanbul ili, Zeytinburnu ilçesi ilkokul düzeyinde öğrenim gören 300 öğrenci katılmıştır. Katılımcıların aile işlevlerinin sağlıklılık durumu Bulut (1990) tarafından uyarlanan "Aile Değerlendirme Ölçeğì" ile davranış problemleri ise Kaner ve Çiçekçi (1999) tarafından uyarlanan "Gözden Geçirilmiş Davranış Problemleri Kontrol Listesi (GGDPKL)" ile değerlendirilmiştir. Elde edilen verilerin analizinde, öğrencilerin aile işlevleri ile davranış problemleri arasındaki ilişkiyi belirlemek için pearson korelasyon katsayısı analizleri uygulanmıştır. Gruplar arasında anlamlı farklılık olup olmadığını belirlemek için Tek Yönlü Varyans Analizi (ANOVA) ve Dunnett's C analizi kullanılmıştır. Yapılan istatistiksel analizler sonrasında, üstün zekâll, zihinsel engelli ve normal zekâya sahip öğrencilerin aile işlevleri ile çocukların davranış problemleri arasında anlamlı düzeyde bir ilişki görülürken, aile işlevlerinin çeşitli alt boyutlarının davranış problemleri için anlamlı yordayıcılar olduğu da bulunmuştur. Ayrıca öğrenci grupları arasında aile işlevleri ve davranış problemleri yönünden istatistiksel olarak anlamlı düzeyde farklılıklar bulunmuştur.

Anahtar Kelimeler: Zekâ, Davranış Problemleri, Aile İşlevleri

* $\quad$ Bu çalışma 11.06.2014 tarihinde Yüksek Lisans Tezi Olarak Yayınlanmıştır.

** Yrd. Doç. Dr., Marmara Üniversitesi, Atatürk Eğitim Fakültesi, İstanbul-Türkiye, nilgun.canel@marmara.edu.tr

*** Arş. Gör., Marmara Üniversitesi, Atatürk Eğitim Fakültesi, İstanbul-Türkiye, haticepinarozdemir@gmail.com 


\begin{abstract}
The objective of the research is to examine the relationship between parenting functions and various behaviour problems of children with mental disabilities, with an average IQ, gifted ones. Besides, that their parenting functions has been healthy/unhealthy and children's behaviour problems have been examined and compared. This is a descriptive research based on the relational screening model. 300 primary school, from Zeytinburnu Province (the European side of Istanbul), contributed to the research. Health status of participants is measured with "Family Assessment Scale" by Bulut (1990), and behaviour problems with "Revised Check List Of Behaviour Problems" by Kaner and Çiçekçi (1999). While analyzing the data, pearson correlation coefficient analysis was used for understanding the relationship between parenting functions and the behaviour problems scale points. On the other hand, One Way Anova and Dunnett's C Test was used for checking whether there were a significance differences in the groups or not. Results after the above mentioned statistical analysis, there has been a statistically significant relationship between healthy parenting functions and behaviour problems for the ones having eithe an average level of IQ, gifted and mental disabilities. It was also found to be significant predictors of behavioral problems of various family functions. Based on the results of the research, including all IQ levels, I can say that there has been a significance difference in terms of parenting functions and behaviour problems.
\end{abstract}

Keywords: Intelligence, Behavior Problems, Parenting Functions

\title{
Giriş
}

Gelişim; öğrenme, yaşantı ve olgunlaşma sonucunda bireyde meydana gelen düzenli ve sürekli değişimi ifade etmektedir (Gander ve Gardiner, 2007). Gelişim alanlarından biri olan bilişsel gelişim alanı; algılama, düşünme, öğrenme, bilgi, bellek, akıl yürütme, sorun çözme gibi birçok zihinsel işlevleri kapsamaktadır (Yıldırım, 2016). Çocuklar için gelişim dönemlerinde benzer gelişim görevleri tanımlanmış olmasına rağmen bütün çocukların bilişsel gelişim becerileri aynı yaşta ve aynı oranda gelişmeyebilir. Bazı çocuklar herhangi bir yaşta diğer çocuklardan daha avantajlı olabilirler. Bazı çocuklar yaşıtlarından daha erken konuşur veya okuyabilirler, matematiksel ve mantıksal işlemlerden daha çabuk anlarlar (Clark, 2015). Bazıları ise daha geç konuşur ve daha zor öğrenir. Çocukluktaki bu ilerlemeler ve bilişsel düzeydeki temel değişiklikler zekâ olarak tanımlanan bir kavram olarak karşımıza çıkmaktadır (Leana-Taşçılar ve Kanlı, 2014). Günümüze dek çeşitli zekâ sınıflandırmaları yapılmış ve zekâyı ölçen birçok test geliştirilmiş. Dünya Sağlık Örgütü’nün (WHO) zekâ sınıflamasını incelediğimizde, insanların zekâ bölümünün düşükten yükseğe doğru yayılan "çan eğrisi” denilen bir eğri ile temsil edildiği görülmüştür. İnsanların büyük bir kısmı bu çan eğrisinin ortalama zekâ bölümü 100 etrafında yığılmış ve bu kısım, normal alan olarak belirlenmiştir (Eripek, 2011). Ortalamanın dışında kalan alanlar ise farklılık gösterenlerin bulunduğu bölge olarak kabul edilmiş, çok az sayıda insanın normalin dışındaki alanda bulunduğu anlaşılmıştır (Eripek ve Vuran, 2009). Bu normal alanın aşağısına baktığımızda karşımızda zihinsel engelli çocukları (Eripek, 2011), üstüne baktığımızda ise üstün zekâlı çocukları görnekteyiz (Sak, 2014; Sternberg, 2000). 
Çocuklar farklı gelişim özelliklerine sahip olsa da, bir çocuğun yakın çevresinden gelen olumsuz etkiler onun hayatında ciddi problemlere sebep olabilir. Gelişim evrelerindeki kritik dönemlerde çocuğun davranışlarına karşı çevresel faktörlerden gelen olumsuz geri bildirimler çocukta duygusal ve davranışsal düzeyde bozukluklara sebep olmaktadır (Smith vd., 2014). Bu olumsuzluklara karşı çocuğun verdiği olağan dışı tepkiler ise "uyum ve davranış bozuklukları" olarak adlandırılmaktadır. Ortaya çıkan davranış problemlerini tespit etmek amacıyla yapılan çalışmalarda ev yaşamı ve okul hayatında etkileşim içerisinde olduğu ailesi, öğretmeni ve akran grupları gibi kaynaklara başvurulmaktadır. Bu nedenle eğitimcilerin davranış problemlerini değerlendirmede önemli bilgi kaynakları oldukları kabul edilmektedir (İkiz, Mete-Otlu ve EkinciVural, 2016). Öğretmenlerin, çocukların özelliklerini objektifolarak tanımlayabildikleri, yaptıkları gözlemlerle benzer gelişimsel özelliklere sahip çocuklar arasında karşılaştırma yapabildikleri ve davranış problemlerini gözlemleyebildikleri anlaşılmaktadır. İlkokul düzeyindeki çocuklarda en sık görülen davranış problemleri ise; yalan söyleme, aşırma, tikler, fobiler, uyum bozuklukları, korkular, davranım bozuklukları, öfke nöbetleri, saldırganlık, hiperaktivite, dikkat eksikliği, depresyondur (Mash ve Barkley, 2014). Bu sorunların oluşması kendi kişilerarası bağlamlarının ürünü olan çocukların kişisel ve sosyal özelliklerinin çevre faktörleriyle olan ilişkisinden kaynaklanmaktadır. Bu etkileşimin en derin ve önemli olduğu yer ise çocuğun doğduğu andan itibaren içerisinde bulunduğu aile ortamıdır.

Aile çocuğun doğduğu andan itibaren kendisini, hayatı ve diğer insanları tanımaya başladığı, kişiliğinin geliştiği, toplumun değer yargılarını, niteliklerini öğrendiği ve deneyimlerini kazandığg temel kurumdur (Gander ve Gardiner, 2007). Çocuğun ilk yıllarda anne ile bağ 1 , baba ve diğer kardeşler ile olan ilişkisi, ailenin yapısal özellikleri çocuklar üzerinde etkilidir. Çeşitli zekâ düzeylerine ve gelişim özelliklerine sahip olmaları çocuğun aileye karşı duyduğu değişmez ihtiyaca sadece farklı nitelikler kazandırmaktadır (Eryılmaz, 2010). Araştırmacılar, ailenin kendi içerisinde farklı işlevlerini tanımlamış, ailenin psiko-sosyal açıdan sağlıklı olma düzeyini her bir işlevin yerine getirilip getirilmemesine göre belirlemiştir (Yavuzer, 2012). Onlara göre aile işlevlerinin temelini, aile içi sevgi atmosferi, aile üyelerinin birbirine gösterdiği ilgi, ailedeki açık iletişim ve belirlenmiş roller, ailede ortaya çıkan problemleri çözme ve kuralları belirleme şekli oluşturur (Morawska ve Sanders, 2009). Ailenin işlevleri incelendiğinde, niteliklerine göre birçok işlev ayrı ayrı ele alınsa da aslında her işlevin bir diğer işlevle bağıntılı olduğu ve birbirlerini tamamlayan işlevler olduğu söylenebilir (Clark, 2015; Early ve Baltes, 2014). Literatür incelendiğinde de aile içi ilişkilerin sağlıksız olması ve aile bireylerinin ailedeki fonksiyonlarını yerine getirmemelerinin çocuklarda davranış problemlerini artırdığını ortaya çıkarmaktadır (Baker, Blacher ve Olsson, 2005; Savi, 2008). Yapılan araştırmalar ve gözlemler sonucunda, aile içi faktörler ile çocukların davranış problemleri arasında ilişki olduğu düşünülmektedir. Araştırma öncesinde öğrenci ve ailelerle yapılan görüşmeler sonucunda çeşitli zekâ düzeylerine sahip öğrencilerin ve onların ailelerinin, kendi içerisinde benzer özelliklere ve sorunlara sahip olduğunun anlaşıldığı gibi birbirinden farklı problemleri ve özellikleri de olduğu fark edilmiştir. Bu sebeple çeşitli zekâ düzeyine sahip öğrencilerin aile işlevleri, davranış problemleri ve farklı demografik özellikleri açısından karşılaştırılmasının incelemeye değer olduğu düşünülmüş ve bu çalışmanın konusunu oluşturmuştur. Bu çalıșmanın amacı üstün zekâlı, normal 
zekâ düzeyine sahip ve zihinsel engelli öğrencilerin aile işlevlerinin sağlıklı olup olmayışı ile çocukların davranış problemleri arasındaki yordayıcı ilişkilerin incelenmesidir. Ayrıca araştırmanın genel amacına uygun olarak aşağıda belirtilen alt problemlere de cevap aranmıştır:

1. Üstün zekâlı, normal zekâ düzeyine sahip ve zihinsel engelli öğrenciler arasında aile işlevleri açısından bir fark var mıdır?

2. Üstün zekâlı, normal zekâ düzeyine sahip ve zihinsel engelli öğrenciler arasında çocukların davranış problemleri açısından bir fark var mıdır?

\section{Yöntem}

\section{Araştırma Modeli}

Üstün zekâlı, normal zekâ düzeyine sahip ve zihinsel engelli öğrencilerin davranış problemleri ile aile işlevleri arasındaki ilişkinin ve çeşitli zekâ düzeylerine sahip bu öğrenci gruplarının aile işlevleri ile davranış problemleri açısından farklılaşıp farklılaşmadığının incelendiği araştırmada ilişkisel tarama modeli uygulanmıştır. Genel tarama modeli, evren hakkında genel bir yargıya varmak amacı ile evrenin tümü ya da ondan alınacak bir örneklem üzerinde yapılan tarama düzenlemeleridir. Genel yargıya varmanın ötesinde, değişkenler arasında ilişkileri ve bağlantıları inceleyen araştırma türü ise ilişkisel tarama yaklaşımı olarak adlandırılır (Büyüköztürk, KılıçÇakmak, Akgün, Karadeniz ve Demirel, 2012).

\section{Evren ve Örneklem}

Araştırmanın çalışma evrenini, 2013-2014 Eğitim-Öğretim yılında İstanbul ili Zeytinburnu ilçesindeki Milli Eğitim Bakanlı̆̆ı’na bağlı normal müfredatta eğitim veren tüm devlet ilkokullarından 1., 2., 3. ve 4. sınıfa ve özel eğitim sınıflarına devam eden 300 kız ve erkek öğrenci oluşturmuştur. Araştırmanın örneklemi iki aşamada belirlenmiştir. Birinci adımda, Zeytinburnu ilçesindeki tüm devlet ilkokulları arasından, amaçlı örnekleme yöntemlerinden 'Ölçüt Örnekleme’ yöntemi ile seçilmiştir. Ölçüt örnekleme yöntemi, araştırma problemi ile ilgili olarak evrende yer alan birimler belli niteliklere sahip, belirlenen ölçütü karşılayan kişiler, nesneler, olaylardan oluşturulabilir (Yıldırım ve Şimşek, 2013). 100 Üstün zekâlı ve 100 zihinsel engelli öğrencinin seçiminde ölçüt Zeytinburnu ilçesi Rehberlik ve Araştırma Merkezi tarafından üstün zekâlı (IQ: 130 ve üstü) ve zihinsel engelli (IQ: 55-70 arası) tanısı almış olmak olarak belirlenmiştir. Ayrıca ilçe devlet okullarında 1-4. Sınıflar arasında eğitimlerine devam eden normal (IQ: 90-110) zekâ sınırları içerinde yer alan 100 öğrenci araştırmaya katılmak üzere belirlenmiştir. İkinci aşama da ise seçkisiz örnekleme yöntemlerinden küme örneklem kullanarak her sınıf düzeyinden benzer oranda öğrenci seçilmiştir (Büyüköztürk vd., 2012). Araştırmada yer almak üzere belirlenen bu öğrencilerin ailelerine ve sınıf öğretmenlerine araştırmada kullanılacak formlar ve ölçekler uygulanmıştır.

\section{Veri Toplama}

Aile Değerlendirme Ölçeği (ADÖ). Çeşitli zekâ düzeylerine sahip öğrencilerin ailelerinin, aile işlevlerini yerine getirip getirmediği konusunda genel bir değerlendirme yapmak ve sorun 
alanlarını ortaya çıkarmak amacıyla Epstein ve Bishop, (1983) tarafından geliştirilen ve Bulut (1990) tarafından uyarlanan "Aile Değerlendirme Ölçeği” kullanılmıştır. Ölçeğin 60 maddesi ve 7 alt boyutu vardır. Ölçekteki her soru 7 alt ölçekten (problem çözme, iletişim, roller, duygusal tepki verebilme, gereken ilgiyi gösterme, davranış kontrolü, genel fonksiyonlar) bir tanesine aittir. Her alt boyuttan alınan toplam puanın yüksekliği, o işlev açısından sağlıksızlığın arttığını gösterir (Bulut, 1990). Bulut (1990) tarafından yapılan Türkçe’ye uyarlama çalışmalarında iç tutarlık için yapılan analizlerde her alt boyut için Cronbach's alfa değerleri problem çözme için .80; iletişim için .42; duygusal tepki verebilme için .59; gereken ilgiyi gösterme için .38; davranış kontrolü için .52 ve genel fonksiyonlar için .86 olarak belirlenmiştir. Ölçeğin yapı geçerliliği bilinen grupların karşılaştırılması tekniği ile sınanmıştır. Her iki grupta elde edilen puan ortalamaları arasındaki fark tüm alt boyutlar için ayrı ayrı $t$ testi ile test edilmiş, tün alt testleri için .001 ile .01 düzeyinde anlamlı bulunmuştur. Bu araştırma kapsamında toplanan veriler ile yapılan analizde ise iç tutarlık katsayısı .85 olarak tespit edilmiştir

Gözden Geçirilmiş Davranış Problemleri Kontrol Listesi (GGDPKL). Çeşitli zekâ düzeylerine sahip öğrencilerin Duygusal ve davranışsal bozukluklarının belirlenmesi amacıyla Quay ve Peterson'un (1996) tarafından geliştirilen ve Kaner ve Çiçekçi (2000) tarafından Türkçe’ye uyarlanan “Gözden Geçirilmiş Davranış Problemleri Kontrol Listesi (GGDPKL)” kullanılmıştır. Ölçek birbirinden bağımsız üç boyuta (Davranım Bozukluğu/Hiperaktivite - İmpulsivite, Depresyon/Dikkat eksikliği ve Sosyalleşmiş Saldırganlıktır) indirilmiştir. Her alt ölçekten alınan puanlar toplanarak her alt ölçek için ayrı toplam puanlar elde edilir (Kaner ve Çiçekci, 2000). Kaner ve Çiçekci, (2000) tarafından yapılan Türkçe’ye uyarlama çalışmalarında iç tutarlık için yapılan analizlerde DB-Hİ, D-DE, SS alt boyutları için Cronbach's alfa değerleri sırasıly .96; .94; .84'dür. Ölçekten, düşük ve yüksek puan alan alt ve üst \% 27 lik grupların her maddeden aldıkları puanların $t$ testi ile ayırt edici geçerlikleri incelenmiş ve tüm maddelerin alt ve üst grupları ayırt ettikleri saptanmıştır. Bu araştırma kapsamında toplanan veriler ile yapılan analizde ise iç tutarlık katsayısı .96 olarak tespit edilmiştir.

\section{Verilerin Analizi}

Deneklere uygulanan ölçeklerden elde edilen veriler kodlanarak bilgisayara yüklenmiştir. Elde edilen bu verilerin çözümlenmesinde SPSS 15.0 istatistik paket programı kullanılmıştır. Elde edilen verilerin analizinde betimsel istatistiklerden frekans (f), yüzde (\%), aritmetik ortalama (X) ve standart sapma (Ss) kullanılmıştır. Elde edilen verilerin normal dağılım gösterdiği $(\mathrm{n}>30)$ ve anlamlılık düzeyi $\mathrm{p}<.05$ olarak kabul edilmiştir. Üstün zekâlı, normal düzeyde zekâya sahip ve zihinsel engelli öğrenci grupları arasında aile işlevlerinin sağlıklı olup olmayışı ve öğrencilerin davranış problemleri açısından bir fark olup olmadığı incelenmiştir. Anlamlı düzeyde farklılaşıp farklılaşmadığını belirlerken normal dağılım gösteren değişkenler için Tek Yönlü Varyans Analizi (ANOVA) ve Dunnett’s C analizi kullanılmıştır. Aile işlevleri, davranış problemleri ölçeklerinden alınan puanlar arasındaki ilişkiyi belirlemek için pearson korelasyon katsayısı, yordama gücünü belirlemek amacıyla çoklu regresyon analizleri uygulanmıştır. 


\section{Bulgular}

$\mathrm{Bu}$ bölümde çeşitli zekâ seviyelerine sahip öğrencilere uygulanan ADÖ, GGDPKL ve kişisel bilgi formundan elde edilen veriler üzerinde yapılan istatistiksel analizler sunulmuştur. Öncelikle araştırma da yer almak üzere oluşturulan örneklem grubunun özelliklerine dair bilgi verilmiştir. Daha sonra grupların ADÖ ile GGDPKL puanlarına göre anlamlı farklılık gösterip göstermediğine ilişkin bulgu ve yorumlara yer verilmiştir. Son olarak ise üstün zekâlı, normal düzeyde zekaya sahip ve zihinsel engelli öğrencilerin aile işlevlerinin sağlıklı olup olmayışı ile çocukların davranış problemleri arasındaki ilişkinin incelenmesine dair korelasyon ve regresyon analizleri sonuçları sunulmuştur.

\section{Tablo I}

Araştırmada Yer Almak Üzere Oluşturulan Örneklem Grubunun Dağılımına İlişkin Frekans ve Yüzde Değerleri

\begin{tabular}{|c|c|c|c|}
\hline Sinif & & Frekans (n) & Yüzde (\%) \\
\hline \multirow{5}{*}{ Üstün Zekâlı } & 1.Sinif & 28 & 28,0 \\
\hline & 2.Sinif & 28 & 28,0 \\
\hline & 3.Sinif & 25 & 25,0 \\
\hline & 4.Sinif & 19 & 19,0 \\
\hline & Total & 100 & 100,0 \\
\hline \multirow{6}{*}{ Zihinsel Engelli } & 1.Sinif & 12 & 12,0 \\
\hline & 2.Sinif & 19 & 19,0 \\
\hline & 3.Sinif & 18 & 18,0 \\
\hline & 4.Sinif & 24 & 24,0 \\
\hline & Özel Eğitim(1-4) & 27 & 27,0 \\
\hline & Total & 100 & 100,0 \\
\hline \multirow{5}{*}{ Normal Zekâ Düzeyi } & 1.Sinif & 15 & 15,0 \\
\hline & 2.Sinif & 34 & 34,0 \\
\hline & 3.Sinif & 28 & 28,0 \\
\hline & 4.Sinif & 23 & 23,0 \\
\hline & Total & 100 & 100,0 \\
\hline
\end{tabular}

Tablo 1'de görüldüğü üzere araştırmaya katılan çeşitli zekâ seviyelerine sahip öğrencilerin 100 tanesi üstün zekâ düzeyine, 100 tanesi zihinsel engele, 100 tanesi ise normal zekâ düzeyine sahiptir. Bu öğrenciler 1, 2, 3 ve 4. sınıftan ve ayrıca özel eğitim sınıflarından seçilmiştir. 
Tablo 2

ADÖ Puanlarının Çeşitli Zekâ Türleri Değişkenine Göre Farklılaşıp Farklılaşmadığını Belirlemek Üzere Yapılan Tek Yönlü Varyans Analizi (ANOVA) sonuçları,

\begin{tabular}{|c|c|c|c|c|c|c|c|c|c|c|c|}
\hline \multicolumn{5}{|c|}{$f, \overline{\mathrm{X}}_{\text {ve }} s$ Değerleri } & \multicolumn{7}{|c|}{ ANOVA Sonuçları } \\
\hline Puan & Grup & $N$ & $\bar{X}$ & $S$ & Var. K. & $\mathbb{K}$ & 8 & $\bigotimes$ & $F$ & $p$ & $\begin{array}{c}\text { Anlamlı } \\
\text { Fark }\end{array}$ \\
\hline \multirow{4}{*}{$\begin{array}{c}\text { Genel } \\
\text { İşlevler }\end{array}$} & Üstün Zekâlı & 100 & 1,4542 & ,31812 & G.Aras1 & 5,089 & 2 & 2,545 & \multirow{4}{*}{16,349} & \multirow{4}{*}{, $000^{* * *}$} & $\ddot{U}-Z^{*}$ \\
\hline & Zihinsel Engelli & 100 & 1,7725 & ,49956 & G.İçi & 46,226 & 297 &, 156 & & & $\ddot{\mathrm{U}}-\mathrm{N}^{*}$ \\
\hline & Normal & 100 & 1,5950 & ,34083 & Toplam & 51,315 & 299 & & & & $N-Z^{*}$ \\
\hline & Toplam & 300 & 1,4542 & ,31812 & & & & & & & \\
\hline \multirow{4}{*}{$\begin{array}{l}\text { Problem } \\
\text { Çözme }\end{array}$} & Üstün Zekâlı & 100 & 1,4633 & ,44165 & G.Aras1 & 4,111 & 2 & 2,055 & \multirow{4}{*}{8,564} & \multirow{4}{*}{, $000^{* * *}$} & $\ddot{U}-Z^{*}$ \\
\hline & Zihinsel Engelli & 100 & 1,7500 & ,56878 & G.İçi & 71,276 & 297 &, 240 & & & \\
\hline & Normal & 100 & 1,6017 & , 44878 & Toplam & 75,387 & 299 & & & & \\
\hline & Toplam & 300 & 1,6050 &, 50213 & & & & & & & \\
\hline \multirow{4}{*}{ İletişim } & Üstün Zekâlı & 100 & 1,4400 & ,34308 & G.Aras1 & 9,403 & 2 & 4,702 & \multirow{4}{*}{25,816} & \multirow{4}{*}{, $000^{* * *}$} & $\ddot{\mathrm{U}}-\mathrm{Z}^{*}$ \\
\hline & Zihinsel Engelli & 100 & 1,8678 &, 52774 & G.İçi & 54,091 & 297 &, 182 & & & $\ddot{\mathrm{U}}-\mathrm{N}^{*}$ \\
\hline & Normal & 100 & 1,5922 & ,38750 & Toplam & 63,494 & 299 & & & & $\mathrm{~N}-\mathrm{Z}^{*}$ \\
\hline & Toplam & 300 & 1,6333 & , 46082 & & & & & & & \\
\hline \multirow{4}{*}{ Roller } & Üstün Zekâlı & 100 & 1,7573 & ,36457 & G.Aras1 & 3,223 & 2 & 1,611 & \multirow{4}{*}{9,076} & \multirow{4}{*}{, $000^{* * *}$} & $\ddot{U}-Z^{*}$ \\
\hline & Zihinsel Engelli & 100 & 2,0009 & ,47852 & G.İçi & 52,728 & 297 &, 178 & & & \\
\hline & Normal & 100 & 1,8173 & ,41318 & Toplam & 55,951 & 299 & & & & $\mathrm{~N}-\mathrm{Z}^{*}$ \\
\hline & Toplam & 300 & 1,8585 & ,43258 & & & & & & & \\
\hline \multirow{4}{*}{$\begin{array}{c}\text { İlgi } \\
\text { Gösterme }\end{array}$} & Üstün Zekâlı & 100 & 2,2000 & ,33302 & G.Aras1 & 3,069 & 2 & 1,534 & \multirow{4}{*}{10,560} & \multirow{4}{*}{, $000^{* * *}$} & $\ddot{\mathrm{U}}-\mathrm{Z}^{*}$ \\
\hline & Zihinsel Engelli & 100 & 2,4386 & ,44312 & G.İçi & 43,156 & 297 &, 145 & & & \\
\hline & Normal & 100 & 2,2614 & ,35869 & Toplam & 46,224 & 299 & & & & $\mathrm{~N}-\mathrm{Z}^{*}$ \\
\hline & Toplam & 300 & 2,3000 & ,39319 & & & & & & & \\
\hline \multirow{4}{*}{$\begin{array}{l}\text { Davranış } \\
\text { Kontrolü }\end{array}$} & Üstün Zekâlı & 100 & 1,9733 & ,27450 & G.Arası & 1,857 & 2 & ,928 & \multirow{4}{*}{6,996} & \multirow{4}{*}{, $001^{\star * *}$} & $\ddot{U}-Z^{*}$ \\
\hline & Zihinsel Engelli & 100 & 2,1589 & , 43372 & G.İçi & 39,409 & 297 & ,133 & & & \\
\hline & Normal & 100 & 2,0211 & ,36688 & Toplam & 41,266 & 299 & & & & $\mathrm{~N}-\mathrm{Z}^{*}$ \\
\hline & Toplam & 300 & 2,0511 & ,37150 & & & & & & & \\
\hline \multirow{4}{*}{$\begin{array}{c}\text { Duygusal } \\
\text { Tepki }\end{array}$} & Üstün Zekâlı & 100 & 1,3317 & ,32952 & G.Aras1 & 19,228 & 2 & 9,614 & \multirow{4}{*}{45,244} & \multirow{4}{*}{, $000^{\star * *}$} & $\ddot{\mathrm{U}}-Z^{*}$ \\
\hline & Zihinsel Engelli & 100 & 1,9417 & ,58955 & G.İçi & 63,111 & 297 & ,212 & & & $\ddot{U}-N^{*}$ \\
\hline & Normal & 100 & 1,5400 & , 42582 & Toplam & 82,339 & 299 & & & & $\mathrm{~N}-\mathrm{Z}^{*}$ \\
\hline & Toplam & 300 & 1,6044 & ,52477 & & & & & & & \\
\hline
\end{tabular}

${ }^{* * *} \mathrm{p} \leq 0,001,{ }^{* *} \mathrm{p} \leq 0,01,{ }^{*} \mathrm{p} \leq 0,05$

Tablo 2'de görüldüğü üzere Aile Değerlendirme Ölçeğinin alt boyutlarına verilen puanlar incelendiğinde, her bir alt boyutta, zihinsel engelli öğrencilerin ailelerinin puanları ortalamasının normal çocukların ailelerine göre; normal çocukların ailelerinin puanları ortalamasının da üstün zekâlı çocukların ailelerinin puan ortalamalarına göre yüksek olduğu görülmüștür. Grup ortalamaları arasındaki bu farklılı̆̆ın anlamlı bir farklılık olup olmadığına dair tek yönlü varyans analizi uygulanmıştır. Yapılan analizler sonucunda, öğrencilerin ailelerinin genel işlevler $(p<0,001)$, problem çözme $(\mathrm{p}<0,001)$, iletişim $(\mathrm{p}<0,001)$, roller $(\mathrm{p}<0,001)$, ilgi gösterme $(\mathrm{p}<0,001)$, davranış 
kontrolü $(\mathrm{p}<0,001)$ ve duygusal tepki $(\mathrm{p}<0,001)$ alt boyutlarına verdikleri cevaplara dair puanların, öğrencilerin zekâ düzeylerine göre farklılık gösterdiği anlaşılmıştır. Bu farkların hangi gruplar arasından kaynaklandığını belirlemek amacıyla tamamlayıcı analizlere geçilmiştir. Bu amaçla önce, varyans homojenliği denetlenmiş, varyansın homojen olmadığ görülmüş ve Dunnett's C analizi uygulanmasına karar verilmiştir. Yapılan analizler sonucunda aile değerlendirme ölçeğinin genel işlevler $(\mathrm{p}<0,05)$, iletişim $(\mathrm{p}<0,05)$ ve duygusal tepki $(\mathrm{p}<0,05)$ boyutlarının puan ortalamalarının bütün öğrenci grupları arasında anlamlı bir farklılık gösterdiği bulgulanmıştır. $\mathrm{Bu}$ üç boyut açısından aile işlevleri incelendiğinde üstün zekâlı öğrencilerin ailelerinin normallere göre; normal düzeydeki öğrencilerin de zihinsel engelli öğrencilerin ailelerine göre daha sağlıklı olduğu söylenilebilir. Aile değerlendirme ölçeğinin $\operatorname{roller}(\mathrm{p}<0,05)$, ilgi gösterme $(\mathrm{p}<0,05)$ ve davranış kontrolü $(\mathrm{p}<0,05)$ boyutları incelendiğinde ise üstün zekâlı öğrenciler ile normal zekâya sahip öğrencilerin ve normal zekâya sahip öğrenciler ile zihinsel engelli öğrencilerin ailelerinin puan ortalamaları arasında anlamlı bir farklılık olduğu anlaşılmıştır. Ölçeğinin problem çözme $(\mathrm{p}<0,05)$ boyutunda ise sadece üstün zekâlı öğrenciler ile zihinsel engelli öğrenciler arasında fark olduğu anlaşılmıştır.

\section{Tablo 3}

GGDPKL Puanlarının Çeşitli Zekâ Türleri Değişkenine Göre Farklılaşıp Farklılaşmadığını Belirlemek Üzere Yapılan Tek Yönlü Varyans Analizi (ANOVA) sonuçları

\begin{tabular}{|c|c|c|c|c|c|c|c|c|c|c|c|}
\hline & $f, \overline{\mathrm{X}}_{\mathrm{ve}} s$ & Değ & rleri & & & & & OVA S & nuçları & & \\
\hline Puan & Grup & $N$ & $\bar{x}$ & $s$ & Var. K. & $\mathbb{K}$ & 8 & $B$ & $F$ & $p$ & $\begin{array}{c}\text { Anlaml } \\
\text { Fark }\end{array}$ \\
\hline \multirow{4}{*}{ DBHİ } & Üstün Zekâlı & 100 & 0619 &, 16480 & G.Arası & 3,923 & 2 & 1,962 & \multirow{4}{*}{36,261} & \multirow{4}{*}{, $000^{* * *}$} & $\ddot{\mathrm{U}}-Z^{\star}$ \\
\hline & Zihinsel Engelli & 100 & ,3041 & ,33312 & G.İçi & 16,068 & 297 &, 054 & & & \\
\hline & Normal & 100 & 0611 & ,15548 & Toplam & 19,991 & 299 & & & & $\mathrm{~N}-\mathrm{Z}^{*}$ \\
\hline & Toplam & 300 & 1423 &, 25857 & & & & & & & \\
\hline \multirow{4}{*}{ DDE } & Üstün Zekâlı & 100 & 0305 & ,07814 & G.Aras1 & 18,587 & 2 & 9,294 & \multirow{4}{*}{127,515} & \multirow{4}{*}{, $000^{\star * *}$} & $\ddot{\mathrm{U}}-\mathrm{Z}^{*}$ \\
\hline & Zihinsel Engelli & 100 & ,5845 & ,41063 & G.İंçi & 21,646 & 297 &, 073 & & & Ü-N* \\
\hline & Normal & 100 & 0870 & ,20957 & Toplam & 40,233 & 299 & & & & $\mathrm{~N}-\mathrm{Z}^{*}$ \\
\hline & Toplam & 300 & ,2340 & ,36682 & & & & & & & \\
\hline \multirow{4}{*}{ SS } & Üstün Zekâlı & 100 & ,0010 & ,01000 & G.Arası & ,191 & 2 & 095 & \multirow{4}{*}{26,815} & \multirow{4}{*}{, $000^{* * *}$} & $\ddot{\mathrm{U}}-\mathrm{Z}^{*}$ \\
\hline & Zihinsel Engelli & 100 & ,0550 & ,10188 & G.İंçi & 1,057 & 297 &, 004 & & & \\
\hline & Normal & 100 & 0020 & ,01407 & Toplam & 1,248 & 299 & & & & $\mathrm{~N}-\mathrm{Z}^{*}$ \\
\hline & Toplam & 300 & 0193 &, 06460 & & & & & & & \\
\hline
\end{tabular}

${ }^{* * *} p \leq 0,001,{ }^{* *} p \leq 0,01,{ }^{*} p \leq 0,05$

Tablo 3'de görüldüğü üzere Gözden Geçirilmiş Davranış Problemleri Kontrol Listesi alt boyutlarına verilen cevaplar incelendiğinde, her bir alt boyut için zihinsel engelli öğrencilerin puanları ortalamasının normal öğrencilere göre, normal zekâya sahip öğrencilerin puanları ortalamasının da, üstün zekâlı gruplara göre yüksek olduğu görülmüştür. Grup ortalamaları 
arasındaki bu farklılığın anlamlı bir farklılık olup olmadığına dair tek yönlü varyans analizi uygulanmıştır. Yapılan öğrencilerin davranış bozukluğu-hiperaktivite $(p<0,001)$, depresyondikkat eksikliği $(\mathrm{p}<0,001)$, sosyal saldırganlık $(\mathrm{p}<0,001)$ alt ölçeklerine verdikleri cevapların, öğrencilerin zekâ düzeylerine farklılık gösterdiği anlaşılmıştır. Bu sonucun farkların hangi gruplar arasından kaynaklandığını belirlemek amacıyla tamamlayıcı analizlere geçilmiştir. Bu amaçla önce, varyans homojenliği denetlenmiş, varyansın homojen olmadı̆̆ 1 görülmüş ve Dunnett's C analizi uygulanmasına karar verilmiştir. Yapılan analizler sonucunda GGDPKL ölçeğindeki depresyon-dikkat eksikliği (DDE) boyutunun çeşitli zekâ düzeylerine sahip bütün öğrenci grupları arasında anlamlı farklılık gösterdiği bulgulanmıştır $(\mathrm{p}<0,05)$. Davranış bozukluğu-hiperaktivite (DBHİ) ve sosyal saldırganlık (SS) boyutları incelendiğinde ise üstün zekâlı öğrenciler ile normal zekâya sahip öğrenciler ve normal zekâya sahip öğrenciler ile zihinsel engelli öğrencilerin puan ortalamaları arasında anlamlı bir farklılık olduğu anlaşılmıştır $(\mathrm{p}<0,05)$. Bu üç boyut açısından davranış problemleri incelendiğinde, üstün zekâlı öğrencilerin davranış problemlerinin; normal düzeydeki öğrencilere; normal zekâya sahip öğrencilerinde zihinsel engelli öğrencilere göre daha az olduğu söylenilebilir.

Tablo 4

Üstün Zekâlı Öğrencilerin ADÖ ve GGDPKL Alt Ölçekleri Arasındaki Ilişkilerin Analizi

\begin{tabular}{ccccccc}
\hline & $\mathbf{n}=\mathbf{1 0 0}$ & & \multicolumn{3}{c}{ GGDPKL } \\
\cline { 2 - 7 } & Üstün Zekâlı & & DBHI & DDE & SS \\
\cline { 2 - 7 } & Genel İşlevler & $\mathrm{r}$ &, 175 &, 101 &, 067 \\
PDölem Çözme & $\mathrm{r}$ &, $232^{*}$ &, 128 &, 008 \\
& İletişim & $\mathrm{r}$ &, 180 &, $201^{*}$ &, 001 \\
Roller & $\mathrm{r}$ &, $351^{* *}$ &, 158 &, 168 \\
& İlgi Gösterme & $\mathrm{r}$ &, 178 &, 052 &, 069 \\
& Davranış Kontrolü & $\mathrm{r}$ &, 000 &, 066 &, 051 \\
Duygusal Tepki & $\mathrm{r}$ &, 005 & 175 &, $358^{* *}$ \\
\hline
\end{tabular}

${ }^{* * *} \mathrm{p} \leq 0,001,{ }^{* *} \mathrm{p} \leq 0,01,{ }^{*} \mathrm{p} \leq 0,05$

Tablo 4’te görüldüğü üzere; üstün zekâlı öğrencilerde ADÖ alt boyutları ile GGDPKL alt boyutları arasındaki ilişkilerin analizi için uygulanan için pearson korelasyon katsayısı analizleri sonucunda üstün zekâlı öğrencilerde ADÖ’nin roller boyutu ile GGDPKL'nin davranım bozukluğu - hiperaktivite ve impulsivite (DBHI) arasında ve ADÖ’nün duygusal tepki faktörü ile GGDPKL’nin sosyalleşmiş saldırganlık (SS) alt boyutları arasında anlamlı pozitif doğrusal bir ilişki olduğu görülmüştür ( $\mathrm{p} \leq 0,01)$. Ayrıca ADÖ’nün Problem çözme faktörü ile GGDPKL’nin davranım bozukluğu - hiperaktivite ve impulsivite (DBHI) arasında ve ADÖnün iletişim boyutu ile depresyon-dikkat eksikliği (DDE) arasında anlamlı pozitif doğrusal bir ilişki olduğu 
görülmüştür ( $\mathrm{p} \leq 0,05)$. Bu durum ailede roller, duygusal tepki, problem çözme ve iletişim işlevlerinin sağlıksızlaştıkça çocuktaki davranış bozukluklarının arttığını göstermektedir.

Tablo 4.I

Üstün Zekâlı Öğrencilerin Aile İşlevlerinin Öğrencilerde Davranım Bozukluğu-Hiperaktivite ve Impulsivitesini (DBHi) Yordamasına iliş̧kin Çoklu Regresyon analizi

\begin{tabular}{|c|c|c|c|c|c|c|}
\hline & B & Standart Hata B & $\beta$ & $\mathbf{t}$ & $p$ & Regresyon Sonucu \\
\hline Genel İşlevler &,- 070 &, 072 &,- 135 &,- 965 & ,337 & \multirow{7}{*}{$\begin{array}{c}\mathrm{R}=, 470 \\
R^{2}=, 221 \\
\mathrm{~F}=3,733 \\
\mathrm{p}<0,001\end{array}$} \\
\hline Problem Çözme &, 078 & ,051 &, 210 & 1,524 & ,131 & \\
\hline Illetişim & ,096 & ,056 & ,201 & 1,722 & ,088 & \\
\hline Roller & ,158 & ,050 & ,349 & 3,144 & ,002 & \\
\hline İlgi Gösterme &, 100 & ,049 & ,203 & 2,045 &, 044 & \\
\hline Davranış Kontrolü &,- 067 & ,061 &,- 112 & $-1,095$ & 276 & \\
\hline Duygusal Tepki &,- 120 & ,055 &,- 241 & $-2,192$ & 031 & \\
\hline
\end{tabular}

${ }^{* * *} \mathrm{p} \leq 0,001,{ }^{* *} \mathrm{p} \leq 0,01,{ }^{*} \mathrm{p} \leq 0,05$

Aile Değerlendirme Ölçeğinin alt boyutlarına göre öğrencilerde (DBHİ)'nin yordanmasına ilişkin çoklu regresyon analizi sonuçları tablo 4.1'de verilmiştir. Genel işlevler, problem çözme, iletişim, roller, davranış kontrolü, ilgi gösterme ve duygusal tepki faktörleri birlikte, öğrencilerin (DBHI) puanları ile kabul edilebilir düzeyde ve anlamlı bir ilişki vermektedir $\left(R=, 470, R^{2}\right.$ $=, 221, \mathrm{p}<0,001)$. Adı geçen yedi değişken birlikte, (DBHI)'deki toplam varyansın yaklaşı \% 22 'sini açıklamıştır. Regresyon katsayılarının anlamlılığına ilişkin doğrusallığın sağlandığ problem çözme ve roller boyutların t-testi sonuçları incelendiğinde ise sadece roller değişkeninin (DBHI) üzerinde anlamlı bir yordayıcı olduğu görülmüştür. Değişkenler arası çoklu bağlantı problemi bulunmamaktadır(Tolerans $>0,33$; VIF $<3$ ).

\section{Tablo 4.2}

Üstün Zekâlı Öğrencilerin Aile İşlevlerinin Öğrencilerde Depresyon-Dikkat Eksikliği (DDE) Yordamasına Ilişkin Çoklu Regresyon Analizi

\begin{tabular}{|c|c|c|c|c|c|c|}
\hline & B & Standart Hata B & $\beta$ & $\mathrm{t}$ & $p$ & Regresyon Sonucu \\
\hline Genel İşlevler &,- 008 & ,037 &,- 033 &,- 218 & ,828 & \multirow{7}{*}{$\begin{array}{c}\mathrm{R}=, 313 \\
R^{2}=, 098 \\
\mathrm{~F}=1.427 \\
\mathrm{p}>0,05\end{array}$} \\
\hline Problem Çözme & ,002 & ,026 & ,010 & 070 & ,945 & \\
\hline İletişim &, 053 &, 029 &, 232 & 1,850 &, 068 & \\
\hline Roller & 027 & ,026 &, 126 & 1,056 & 294 & \\
\hline İlgi Gösterme & ,008 &, 025 &, 034 & 320 & ,750 & \\
\hline Davranış Kontrolü &,- 056 & ,031 &,- 198 & $-1,802$ & 075 & \\
\hline Duygusal Tepki &, 019 & ,028 & 079 &, 672 & ,503 & \\
\hline
\end{tabular}

${ }^{* * *} \mathrm{p} \leq 0,001,{ }^{* *} \mathrm{p} \leq 0,01,{ }^{*} \mathrm{p} \leq 0,05$ 
Aile Değerlendirme Ölçeğinin alt boyutlarına göre öğrencilerde (DDE)'nin yordanmasına ilişkin çoklu regresyon analizi sonuçları tablo 4.2'de verilmiştir. Genel işlevler, problem çözme, iletişim, roller, davranış kontrolü, ilgi gösterme ve duygusal tepki faktörleri birlikte, öğrencilerin (DDE) puanları ile anlamlı bir ilişki vermemektedir $\left(\mathrm{R}=, 313, R^{2}=, 098, \mathrm{p}>0,05\right)$.

Tablo 4.3

Üstün Zekâlı Öğrencilerin Aile İşlevlerinin Öğrencilerde Sosyalleşmiş Saldırganlık (SS) Yordamasına Ilişkin Çoklu Regresyon Analizi

\begin{tabular}{|c|c|c|c|c|c|c|}
\hline & B & Standart Hata B & $\beta$ & $\mathrm{t}$ & $p$ & Regresyon Sonucu \\
\hline Genel İşlevler & -005 &, 005 &, 002 &, 012 & ,991 & \multirow{7}{*}{$\begin{array}{c}\mathrm{R}=, 422 \\
R^{2}=, 178 \\
\mathrm{~F}=2,842 \\
\mathrm{p}<0,01\end{array}$} \\
\hline Problem Çözme &,- 002 & ,003 &,- 099 &,- 701 & 485 & \\
\hline İletişim &,- 006 &, 003 &,- 196 & $-1,634$ &, 106 & \\
\hline Roller &, 003 & ,003 &, 120 & 1,049 & ,297 & \\
\hline İlgi Gösterme &,- 001 &, 003 &,- 045 &,- 441 &, 532 & \\
\hline Davranış Kontrolü & -005 & ,004 &,- 002 &,- 020 & ,984 & \\
\hline Duygusal Tepki & ,014 & ,003 &, 452 & 4,006 & ,000 & \\
\hline
\end{tabular}

Aile Değerlendirme Ölçeğinin alt boyutlarına göre öğrencilerde (SS)'in yordanmasına ilişkin çoklu regresyon analizi sonuçları tablo 4.3'de verilmiştir. Genel işlevler, problem çözme, iletişim, roller, davranış kontrolü, ilgi gösterme ve duygusal tepki faktörleri birlikte, öğrencilerin (SS) puanları ile kabul edilebilir düzeyde ve anlamlı bir ilişki vermektedir $\left(\mathrm{R}=, 422, R^{2}=, 178, \mathrm{p}<0,01\right)$. Adı geçen yedi değişken birlikte (SS)'daki toplam varyansın yaklaşık \% 18'ini açıklamıştır. Regresyon katsayılarının anlamlılığına ilişkin t-testi sonuçları incelendiğinde ise sadece doğrusallığın sağlandığ duygusal tepki gösterme değişkeninin (SS) üzerinde anlamlı bir yordayıcı olduğu görülmüştür. Değişkenler arası çoklu bağlantı problemi bulunmamaktadır(Tolerans $>0,33$; VIF $<3$ ).

Tablo 5;

Zihinsel engelli öğrencilerin ADÖ Ve GGDPKL Ölçekleri Arasındaki Illişkilerin Analizi

\begin{tabular}{|c|c|c|c|c|c|}
\hline & \multirow{2}{*}{$\begin{array}{c}\mathrm{n}=100 \\
\text { Normal }\end{array}$} & & \multicolumn{3}{|c|}{ GGDPKL } \\
\hline \multirow{8}{*}{ ADÖ } & & & DBHİ & $\mathrm{DDE}$ & SS \\
\hline & Genel İşlevler & $\mathrm{r}$ &, 135 &, 156 &, $242^{*}$ \\
\hline & Problem Çözme & $\mathrm{r}$ & 077 & ,095 &, $356^{\star *}$ \\
\hline & İletişim & $\mathrm{r}$ & ,148 &, $296^{\star *}$ &, $231^{*}$ \\
\hline & Roller & $\mathrm{r}$ &, $215^{\star}$ &, $213^{\star}$ &, 144 \\
\hline & İlgi Gösterme & $\mathrm{r}$ &, 071 &, 054 & 013 \\
\hline & Davranış Kontrolü & $\mathrm{r}$ & ,148 & 143 & ,148 \\
\hline & Duygusal Tepki & $\mathrm{r}$ &,- 099 & , 195 &, 088 \\
\hline
\end{tabular}

${ }^{* * *} \mathrm{p} \leq 0,001,{ }^{* *} \mathrm{p} \leq 0,01,{ }^{*} \mathrm{p} \leq 0,05$ 
Tablo 5’te görüldüğü üzere; zihinsel engelli öğrencilerin aile davranışlar ölçeği alt boyutları ile davranış problemleri ölçeği alt boyutları arasındaki ilişkilerin analizi için uygulanan için pearson korelasyon katsayısı analizleri sonucunda normal düzeyde zekaya sahip öğrencilerde, ADÖ’nin problem çözme boyutu GGDPKL'nin sosyalleşmiş saldırganlık (SS) boyutu ve iletişim boyutu ile depresyon-dikkat eksikliği (DDE) arasında anlamlı pozitif doğrusal bir ilişki olduğu görülmüştür ( $\mathrm{p} \leq 0,01)$. ADÖ'nin roller boyutu ile GGDPKL’nin davranım bozukluğu - hiperaktivite ve impulsivite (DBHİ) ve depresyon-dikkat eksikliği (DDE) arasında anlamlı pozitif doğrusal bir ilişki olduğu görülmüştür ( $\mathrm{p} \leq 0,05)$. Ayrıca genel işlevler ve iletişim boyutu ile sosyal saldırganlık (SS) arasında da anlamlı pozitif doğrusal bir ilişki olduğu görülmüştür ( $\mathrm{p} \leq 0,05)$. Ortaya çıkan sonuç ailedeki bu işlevlerin sağlıksız hale gelmesiyle çocuklardaki davranış problemlerinin fazlalaştığ1 göstermiştir.

Tablo 5.I

Zihinsel engelli öğrencilerin Aile İşlevlerinin Öğrencilerde Davranım Bozukluğu-Hiperaktivite ve Impulsivitesini (DBHi) Yordamasına Ilişkin Çoklu Regresyon Analizi

\begin{tabular}{|c|c|c|c|c|c|c|}
\hline & B & Standart Hata B & $\beta$ & $\mathrm{t}$ & $p$ & Regresyon Sonucu \\
\hline Genel İşlevler &, 040 &, 113 &, 060 &, 354 & ,724 & \multirow{7}{*}{$\begin{array}{c}\mathrm{R}=, 412 \\
R^{2}=, 170 \\
\mathrm{~F}=2,689 \\
\mathrm{p}<0,01\end{array}$} \\
\hline Problem Çözme & ,014 & 074 & ,024 & , 186 & 853 & \\
\hline İletişim & , 139 &, 087 &, 220 & 1,601 & ,113 & \\
\hline Roller & ,215 & 094 & ,308 & 2,273 & 025 & \\
\hline İlgi Gösterme & ,018 & ,081 & ,024 & 228 & ,820 & \\
\hline Davranış Kontrolï & 047 & 089 & 061 &, 527 & 600 & \\
\hline Duygusal Tepki &,- 286 & 079 &,- 506 & $-3,627$ &, 000 & \\
\hline
\end{tabular}

${ }_{* * *} \mathrm{p} \leq 0,001,{ }^{* *} \mathrm{p} \leq 0,01,{ }^{*} \mathrm{p} \leq 0,05$

Aile Değerlendirme Ölçeğinin alt boyutlarına göre öğrencilerde (DBHİ)'nin yordanmasına ilişkin çoklu regresyon analizi sonuçları tablo 5.1'de verilmiştir. Genel işlevler, problem çözme, iletişim, roller, davranış kontrolü, ilgi gösterme ve duygusal tepki faktörleri birlikte, öğrencilerin (DBHI) puanları ile kabul edilebilir düzeyde ve anlamlı bir ilişki vermektedir $\left(\mathrm{R}=, 412, R^{2}=, 170, \mathrm{p}<\right.$ ,01). Adı geçen yedi değişken birlikte, (DBHİ)'deki toplam varyansın yaklaşık \% 17'sini açıklamıştır. Regresyon katsayılarının anlamlılığına ilişkin t-testi sonuçları incelendiğinde ise, doğrusallığın sağlandığı roller değişkeninin (DBHİ) üzerinde anlamlı bir yordayıcı olduğu görülmüştür. Değişkenler arası çoklu bağlantı problemi bulunmamaktadır(Tolerans >0,33; VIF <3). 
Çeşitli Zekâ Düzeylerine Sahip İlkokul Öğrencilerinin Davranış Problemleri ile Aile İşlevleri Arasındaki İlişkinin İncelenmesi

Tablo 5. 2

Zihinsel Engelli Öğrencilerin Aile İşlevlerinin Öğrencilerde Depresyon-Dikkat Eksikliği (DDE) Yordamasına Ilişkin Çoklu Regresyon Analizi

\begin{tabular}{|c|c|c|c|c|c|c|}
\hline & B & Standart Hata B & $\beta$ & t & $p$ & Regresyon Sonucu \\
\hline Genel İşlevler &,- 081 & , 145 &,- 098 &,- 556 & ,580 & \multirow{7}{*}{$\begin{array}{c}\mathrm{R}=, 317 \\
R^{2}=, 100 \\
\mathrm{~F}=1,468 \\
\mathrm{p}>0,05\end{array}$} \\
\hline Problem Çözme &,- 036 & ,095 &,- 050 &,- 378 & ,707 & \\
\hline İletişim & ,239 &, 112 & ,307 & 2,144 & ,035 & \\
\hline Roller & ,084 &, 121 & 098 & ,693 & ,490 & \\
\hline İlgi Gösterme &,- 032 & , 104 &,- 035 &,- 311 & ,756 & \\
\hline Davranış Kontrolï &, 053 &, 114 & ,056 & ,465 & ,643 & \\
\hline Duygusal Tepki & ,009 & 101 &, 012 & ,086 & ,932 & \\
\hline
\end{tabular}

${ }^{* * *} \mathrm{p} \leq 0,001,{ }^{* *} \mathrm{p} \leq 0,01,{ }^{*} \mathrm{p} \leq 0,05$

Aile Değerlendirme Ölçeğinin alt boyutlarına göre öğrencilerde (DDE)'nin yordanmasına ilişkin çoklu regresyon analizi sonuçları tablo 5.2'de verilmiştir. Genel işlevler, problem çözme, iletişim, roller, davranış kontrolü, ilgi gösterme ve duygusal tepki faktörleri birlikte, öğrencilerin (DDE) puanları ile anlamlı bir ilişki vermemektedir $\left(\mathrm{R}=, 317, R^{2}=, 100, \mathrm{p}>0,05\right)$.

Tablo 5. 3

Zihinsel Engelli Öğrencilerin Aile Işlevlerinin Öğrencilerde Sosyalleşmiş Saldırganlık (SS) Yordamasına Iilişkin Çoklu Regresyon Analizi

\begin{tabular}{|c|c|c|c|c|c|c|}
\hline & B & Standart Hata B & $\beta$ & $\mathbf{t}$ & $p$ & Regresyon Sonucu \\
\hline Genel İşlevler & ,010 & 035 & ,049 & ,289 & ,773 & \multirow{7}{*}{$\begin{array}{c}\mathrm{R}=, 399 \\
R^{2}=, 159 \\
\mathrm{~F}=2,489 \\
\mathrm{p}<0,05\end{array}$} \\
\hline Problem Çözme & ,061 &, 023 & ,338 & 2,648 & ,010 & \\
\hline İletişim &, 035 & ,027 &, 182 & 1,314 & , 192 & \\
\hline Roller &,- 003 &, 029 &,- 013 &,- 096 & 924 & \\
\hline İlgi Gösterme &,- 007 & ,025 &,- 032 &,- 294 & ,769 & \\
\hline Davranış Kontrolï &, 011 & 027 &, 046 & ,391 & ,697 & \\
\hline Duygusal Tepki &,- 038 &, 024 &,- 222 & $-1,581$ & ,117 & \\
\hline
\end{tabular}

${ }^{* * *} \mathrm{p} \leq 0,001,{ }^{* *} \mathrm{p} \leq 0,01,{ }^{*} \mathrm{p} \leq 0,05$

Aile Değerlendirme Ölçeğinin alt boyutlarına göre öğrencilerde (SS)'ın yordanmasına ilişkin çoklu regresyon analizi sonuçları tablo 5.3'de verilmiştir. Genel işlevler, problem çözme, iletişim, roller, davranış kontrolü, ilgi gösterme ve duygusal tepki faktörleri birlikte, öğrencilerin (SS) puanları ile kabul edilebilir düzeyde ve anlamlı bir ilişki vermektedir $\left(\mathrm{R}=, 309, R^{2}=, 159, \mathrm{p}<\right.$ ,05). Adı geçen yedi değişken birlikte (SS)'daki toplam varyansın yaklaşık \% 16’sını açıklamıştır. Regresyon katsayılarının anlamlılığına ilişkin doğrusallığın sağlandığı genel işlevler, problem çözme ve iletişim boyutların t-testi sonuçları incelendiğinde ise sadece problem çözme değişkeninin (SS) üzerinde anlamlı bir yordayıcı olduğu görülmüştür. Değişkenler arası çoklu bağlantı problemi bulunmamaktadır(Tolerans $>0,33$; VIF $<3$ ). 


\section{Tablo 6}

Normal Zekô Düzeyine Sahip Öğrencilerin ADÖ ve GGDPKL Ölçekleri Arasındaki Illişkilerin Analizi

\begin{tabular}{ccccccc}
\hline & $\mathrm{n}=100$ & & \multicolumn{3}{c}{ GGDPKL } \\
\cline { 2 - 6 } & Zihinsel Engelli & & DBHI & DDE & SS \\
\cline { 2 - 6 } ADÖ & Genel İşlevler & $\mathrm{r}$ &, 092 &, 138 &,- 058 \\
& Problem Çözme & $\mathrm{r}$ &,- 052 &, 154 &, 181 \\
& İletişim & $\mathrm{r}$ &,- 038 &, 052 &, 089 \\
Roller & $\mathrm{r}$ &, 029 &, 084 &,- 079 \\
& İlgi Gösterme & $\mathrm{r}$ &, 019 &, 019 &,- 105 \\
& Davranı̧ Kontrolü & $\mathrm{r}$ &,- 024 &, 047 &,- 030 \\
& Duygusal Tepki & $\mathrm{r}$ &, $203^{*}$ &, $233^{*}$ &, $239^{*}$ \\
\hline
\end{tabular}

${ }^{* * *} \mathrm{p} \leq 0,001,{ }^{* *} \mathrm{p} \leq 0,01,{ }^{*} \mathrm{p} \leq 0,05$

Tablo 6'da görüldüğü üzere; normal zekâ düzeyine sahip öğrencilerde ADÖ alt boyutları ile GGDPKL alt boyutları arasındaki ilişkilerin analizi için uygulanan için pearson korelasyon katsayısı analizleri sonucunda zihinsel engelli öğrencilerde, ADÖ’nin duygusal tepki faktörü ile GGDPKL'nin davranım bozukluğu - hiperaktivite ve impulsivite (DBHI), depresyon-dikkat eksikliği (DDE) ve sosyalleşmiş saldırganlık (SS) alt boyutları arasında anlamlı düzeyde pozitif doğrusal bir ilişki olduğu görülmüştür $(\mathrm{p} \leq 0,05)$. Ortaya çıan sonuç ailedeki bu işlevin sağlıksız hale gelmesiyle çocuklardaki davranış problemlerinin fazlalaştığı göstermiştir.

Tablo 6.I

Normal Zekâ Düzeyine Sahip Öğrencilerin Aile İşlevlerinin Öğrencilerde Davranım BozukluğuHiperaktivite ve Impulsivitesini (DBHi) Yordamasına Illişkin Çoklu Regresyon Analizi

\begin{tabular}{|c|c|c|c|c|c|c|}
\hline & B & $\begin{array}{c}\text { Standart } \\
\text { Hata B }\end{array}$ & $\beta$ & $\mathrm{t}$ & $p$ & Regresyon Sonucu \\
\hline Genel İşlevler &, 082 &, 062 & , 181 & 1,323 & , 189 & \multirow{3}{*}{$\begin{array}{c}\mathrm{R}=, 302 \\
R^{2}=, 091\end{array}$} \\
\hline Problem Çözme &,- 049 & 043 &,- 141 & $-1,136$ & 259 & \\
\hline İletişim &,- 081 & 054 &,- 202 & $-1,487$ &, 140 & \\
\hline Roller &, 023 &, 048 &, 060 & 477 & ,635 & \multirow{4}{*}{$\begin{array}{c}F=1,318 \\
p>0,05\end{array}$} \\
\hline İlgi Gösterme &,- 041 & 050 &,- 093 &,- 812 & ,419 & \\
\hline Davranış Kontrolü &,- 026 & 046 &,- 062 &,- 572 &, 569 & \\
\hline Duygusal Tepki &, 105 &, 042 & ,286 & 2,476 &, 015 & \\
\hline
\end{tabular}

${ }^{* * *} p \leq 0,001,{ }^{* *} p \leq 0,01,{ }^{*} p \leq 0,05$

Aile Değerlendirme Ölçeğinin alt boyutlarına göre öğrencilerde (DBHİ)'nin yordanmasına ilişkin çoklu regresyon analizi sonuçları tablo 6.1'de verilmiştir. Genel işlevler, problem çözme, 
iletişim, roller, davranış kontrolü, ilgi gösterme ve duygusal tepki faktörleri birlikte, öğrencilerin (DBHİ) puanları ile anlamlı bir ilişki vermemektedir $\left(\mathrm{R}=, 302, R^{2}=, 091, \mathrm{p}>0,05\right)$.

Tablo 6.2

Normal Zekâ Düzeyine Sahip Öğrencilerin Aile İşlevlerinin Öğrencilerde Depresyon-Dikkat Eksikliği (DDE) Yordamasına İlişkin Çoklu Regresyon Analizi

\begin{tabular}{|c|c|c|c|c|c|c|}
\hline & B & $\begin{array}{c}\text { Standart } \\
\text { Hata B }\end{array}$ & $\beta$ & $\mathrm{t}$ & $p$ & Regresyon Sonucu \\
\hline Genel İşlevler & 051 &, 084 & 083 & 609 & ,544 & \multirow{7}{*}{$\begin{array}{c}\mathrm{R}=, 285 \\
R^{2}=, 081 \\
\mathrm{~F}=1,163 \\
\mathrm{p}>0,05\end{array}$} \\
\hline Problem Çözme & 053 & 058 &, 113 & 899 & ,371 & \\
\hline İletişim &,- 093 & 074 &,- 172 & $-1,256$ & ,212 & \\
\hline Roller & 014 & ,065 & ,027 & 210 & 834 & \\
\hline İlgi Gösterme &,- 032 & ,068 &,- 055 &,- 476 & ,636 & \\
\hline Davranış Kontrolü & 004 & ,062 & ,008 & ,069 & ,945 & \\
\hline Duygusal Tepki & , 126 & 057 & ,257 & 2,208 &, 030 & \\
\hline
\end{tabular}

${ }^{* * *} \mathrm{p} \leq 0,001,{ }^{* *} \mathrm{p} \leq 0,01,{ }^{*} \mathrm{p} \leq 0,05$

Aile Değerlendirme Ölçeğinin alt boyutlarına göre öğrencilerde (DDE)'nin yordanmasına ilişkin çoklu regresyon analizi sonuçları tablo 6.2'de verilmiştir. Genel işlevler, problem çözme, iletişim, roller, davranış kontrolü, ilgi gösterme ve duygusal tepki faktörleri birlikte, öğrencilerin (DDE) puanları ile anlamlı bir ilişki vermemektedir $\left(\mathrm{R}=, 285, R^{2}=, 081, \mathrm{p}>0,05\right)$.

Tablo 6.3

Normal Zekâ Düzeyine Sahip Öğrencilerin Aile İşlevlerinin Öğrencilerde Sosyalleşmiş Saldırganlık (SS) Yordamasına Iilişkin Çoklu Regresyon Analizi

\begin{tabular}{|c|c|c|c|c|c|c|}
\hline & B & $\begin{array}{c}\text { Standart } \\
\text { Hata B }\end{array}$ & $\beta$ & $\mathrm{t}$ & $p$ & Regresyon Sonucu \\
\hline Genel İşlevler &,- 008 & ,005 &,- 194 & $-1,466$ & ,146 & \multirow{7}{*}{$\begin{array}{c}\mathrm{R}=, 382 \\
R^{2}=, 146 \\
\mathrm{~F}=2,246 \\
\mathrm{p}<0,05\end{array}$} \\
\hline Problem Çözme &, 008 &, 004 & ,242 & 2,003 &, 048 & \\
\hline İletişim & ,001 & ,005 & ,033 & ,254 & 800 & \\
\hline Roller &,- 005 &, 004 &,- 157 & $-1,279$ & ,204 & \\
\hline İlgi Gösterme &,- 002 & 004 &,- 060 &,- 536 & ,593 & \\
\hline Davranış Kontrolï & 000 & 004 &,- 006 &,- 053 & ,958 & \\
\hline Duygusal Tepki & 010 & ,004 & ,290 & 2,585 & 011 & \\
\hline
\end{tabular}

${ }^{* * *} p \leq 0,001,{ }^{* *} p \leq 0,01,{ }^{*} p \leq 0,05$

Aile Değerlendirme Ölçeğinin alt boyutlarına göre öğrencilerde (SS)'`n yordanmasına ilişkin çoklu regresyon analizi sonuçları tablo 6.3'de verilmiştir. Genel işlevler, problem çözme, iletişim, roller, davranış kontrolü, ilgi gösterme ve duygusal tepki faktörleri birlikte, öğrencilerin SS puanları ile kabul edilebilir düzeyde ve anlamlı bir ilişki vermektedir $\left(\mathrm{R}=, 382, R^{2}=, 146, \mathrm{p}<0,05\right)$. Adı 
geçen yedi değişken birlikte (SS)'daki toplam varyansın yaklaşık \% 15'ini açıklamıştır. Regresyon katsayılarının anlamlılığına ilişkin t-testi sonuçları incelendiğinde ise, doğrusallığın sağlandığı duygusal tepki verme değişkeninin (SS) üzerinde anlamlı bir yordayıcı olduğu görülmüştür. Değişkenler arası çoklu bağlantı problemi bulunmamaktadır(Tolerans $>0,33$; VIF $<3$ ).

\section{Tartışma}

Üstün zekâlı, normal düzeyde zekâya sahip ve zihinsel engelli öğrencilerin aile işlevlerinin sağlıklı olup olmayışı ile çocukların davranış problemleri arasındaki ilişkinin incelendiği bu araştırmada, aynı zamanda çeşitli zekâ düzeylerine sahip bu öğrenci gruplarının aile işlevleri ve davranış problemlerine göre farklılaşıp farklılaşmadığı araştırılmıştır.

Araştırmanın sonuçları incelendiğinde üstün zekâlı, normal zekâ düzeyine sahip ve zihinsel engelli öğrencilerin aile işlevleri açısından aralarında anlamlı bir farklılık olduğu görülmüştür. Araştırma sonucuna göre üstün zekâlı öğrenciler aile işlevleri açısından en sağlıklı aileler olarak görülmektedir. Zihinsel engelli çocukların ailelerinin aile işlevleri de en sağlıksız aileler olarak görülmektedir. Zihinsel engelli öğrencilerin aile işlevlerindeki zayıflığının nedenleri olarak ailede zihinsel engelli bir çocuğun varlığının aile içi etkileşime yansıması, kalıtımsal etmenler ve gelişim alanlarının birbirini olumsuz etkilemesi olarak gösterilebilir. Özellikle aile içerisinde zihinsel engeli bulunan bir çocuğun olması, aile içindeki sağlıksız üyenin gelişimsel ihtiyaçlarının karşılanması sorun çözme biçimleri, rol paylaşımı gibi tüm aile işlevlerini etkilemektedir. ADÖ ile yapılan çalışmalara bakıldığında, ruhsal sorunu olan üyesi bulunan ailelerin, bulunmayan ailelere göre aile işlevleri daha sağlıksız bulunmuştur (Büküşoğlu, Aysan ve Erermiş, 2001). Literatür incelendiğinde engelli bireye sahip ailelerin yaşam kalitelerinin düşük olduğu bulgulanmıştır (Chandler, 2015; May ve Kennedy, 2010; Yee Lim ve Wong, 2009). Üstün zekâl, normal zekâya sahip ve zihinsel engelli öğrencilerin davranış problemleri açısından, öğrencilerin zekâ düzeylerine göre farklılık gösterdiği anlaşılmıştır. Tüm boyutlar açısından üstün zekâlılar ve zihinsel engelliler arasında anlamlı bir fark vardır. Zihinsel engelli öğrencilerde saldırganlık, zıtlaşma, arkadaşlarıyla birlikte yıkıcı faaliyetler, topluma ters düşen hareketler, aşırı hareketlilik, dikkatini toparlayamama, gibi davranış bozuklukları daha fazla görülmüştür. Bunun nedeni olarak, zihinsel gelişimdeki gerilik sonucu günlük yaşamlarında yetersizlik ve uyumsuzluk yaşayan çocukların hissettiği olumsuz benlik algısı, zayıf özgüven, karamsarlık ve kendini var edebildiği yıkıcı davranışlara başvurabilmesi gösterilebilir (Volkmar ve Dykens, 2002). Normal zekâya sahip öğrencilerde dikkat dağınıklığı, odaklanamama, günlük etkinliklerde unutkanlık, basit hatalar, dikkatin kolayca dağılması, uyum sorunları ve kaygı gibi ölçeğinin alt boyutundaki davranışlar (Kaner ve Çiçekçi, 2000) üstün zekâlı öğrencilere göre daha fazla problem oluşturmaktadır. Nail ve Evans’in (1997) araştırmasında üstün zekâlı çocukların normal zekâ düzeyine sahip çocuklara oranla daha az uyum problemi gösterdiklerini ifade etmiştir. Yapılan bazı araştırmalarda, sosyal davranışlarda yaşanan sorunlar yönünden üstün zekâlı çocuklar ile normal zekâ düzeyine sahip çocuklar arasında bir fark olmadığı bulgulanmışken (Lee, Olszewski-Kubillius ve Thomson, 2012), bazılarında ise sosyal davranış özellikleri açısından üstün yetenekli çocukların daha iyi özellikler sergilediğine değinilmiştir (Freitaş, Del Prette ve Del 
Prette, 2014). Çeşitli araştırmalarda üstün yetenekli öğrencilerin sosyal ve duygusal uyumlarının normal zekâ düzeyine sahip öğrencilerle karşılaştırıldığı araştırmada üstün yetenekli öğrencilerde sosyal uyum için beklenen normlardan daha iyi olduğu sonucu çıkmıştır (Neihart, 1999). Ancak bazı araştırmacılar yaptıkları araştırmalarda, üstün zekâlı çocukların sosyal davranışlarında problem yaşadıkları sonucunu bulgulamıştır (Fonseca, 2011). Cornell ve Grossberg (1989), yüksek zekâ ile sosyal uyum arasında pozitif bir ilişki olduğunu ifade etmiştir.

Üstün zekâlı, normal zekâ düzeyine sahip ve zihinsel engelli öğrencilerin aile işlevlerinin sağlıklı olup olmayışı ile çocukların davranış problemleri arasındaki ilişkinin incelendiği bu araştırmada üstün zekâlı öğrencilerin bazı aile işlevleri ile çocuklardaki davranış bozuklukları arasında bir ilişki olduğu görülmüştür. Sonuçlar, ailede roller, duygusal tepki, problem çözme ve iletişim işlevlerinin sağlıksızlaştıkça çocuktaki davranış bozukluklarının arttığını göstermektedir. Üstün zekâlı öğrencilerin aile işlevlerinin öğrencilerde davranış bozukluklarını yordamasına ilişkin yapılan çoklu regresyon analizi sonuçlarında aile içi roller, problem çözme ve duygusal tepki boyutlarının yordayıcılar olarak bulgulandığı görülmüştür. Literatür incelendiğinde aile içinde demokratik düzenin olmaması, ortak karar alınamaması, rol çatışmaları ve rollerin yerine getirilememesi ile ilgili durumlarda kaynaklanan sorunlar aile dengesinin bozulmasına ve çocuklarda davranış bozukluklarının artmasına sebep olabilmektedir (Savi, 2008). Aile içi duygusal tepki faktörünün ise ayrıca öğrencilerin sosyalleşmiş saldırganlık problemlerini en yüksek yordama gücüne sahip olan değişken olduğu anlaşılmıştır. Son zamanlarda yapılan araştırmalarda ebeveynlerin duygusal ve ilgili yönü arttıkça dışsallaştırılmış davranış problemlerinin azaldığı tespit edilmiştir (Prinzie vd., 2004). Zihinsel engelli öğrenci grubundaki öğrencilerin aile işlevleri ile çocuklardaki davranış bozuklukları arasında bir ilişki olduğu anlaşılmıştır. Ortaya çıkan sonuç ailedeki bazı işlevlerin sağlıksız hale gelmesiyle çocuklardaki davranış problemlerinin fazlalaştığı göstermiştir. Yapılan çoklu regresyon analizinde, ise aile içerisindeki problem çözme, roller boyutlarının çocukların davranış problemlerinde en önemli yordayıcılar olarak bulgulandığı görülmüştür. Yapılan araştırmalarda aile içindeki etkileşimin olumlu ve destekleyici bir yapıya sahip olması çocuğun kendini ifade etme, başkalarını anlayabilme ve problemler karşısında uygun çözüm yolları geliştirmesine yardımcı olduğu görülmüştür (Bosco vd., 2003). Aile içerisinde var olan sorunlara yetersiz çözüm bulma yöntemleri, çocuğun ihtiyaçlarına ve problemlerine karşı duyarsız davranma, çocuğun rol model alacağı tutarlı bir yapıyı sergilememe, zihinsel engelli çocuğun gereksinimlerini okuldan kaçma, madde kullanma, zıtlaşma, çete üyeliği gibi davranış problemleri üzerinden gidermeye çalıştığı görülmektedir. Bu tip ailelerde yetişen çocuklar, öfke ve saldırganlığı bir sorun çözme tekniği olarak kendi ailelerinden model alıp, öğrendikleri bu sağlıksız baş etme becerilerini sosyal çevrede kullanabilmektedirler (Avc1, 2006). Türkiye'de Başbakanlık Aile Araştırma Kurumu'nun (1998) yapmış olduğu araştırmada, anne-babaları tarafından dövüldüğünü söyleyen çocukların şiddet davranışı gösterme düzeylerinin diğer gruptakilere göre daha yüksek olduğu saptanmıştır. Araştırma sonuçları sevgi ve özenin az olduğu aile ortamında çocuğun kendine güveninin az olacağı dolayısıyla içe kapanık ve güvensiz olacă̆ını ortaya koymuştur (Tabak, 2007). 
Normal zekâ düzeyine sahip öğrencilerin aile işlevleri ve çocukların davranış problemleri arasındaki ilişkiye dair bulgular ele alındığında yalnızca aile içerisindeki duygusal tepki işlevleri ile çocuklardaki davranış bozuklukları arasında anlamlı bir ilişki olduğu anlaşılmıştır. Normal zekâ düzeyine sahip öğrencilerin aile işlevlerinin öğrencilerde davranış problemlerine ilişkin yapılan çoklu regresyon analizinde yalnızca aile içi duygusal tepki verme boyutunun anlamlı bir yordayıcı olduğu anlaşılmıştır. Literatür incelendiğinde yapılan araştırmalarda, aile işlevleri ve davranış problemleri arasındaki ilişkiye bakıldığında, aile içinde problem çözme, iletişim, roller, duygusal tepki verebilme, gereken ilgiyi gösterme, davranış kontrolü ve genel işlevler alanlarında yaşanan problemlerin, içselleştirilmiş ve dışsallaştırılmış davranış problemleri üzerinde pozitif yönde anlamlı etkilerinin olduğu gözlenmiştir (Sözügeçer, 2011). Baker vd., (2005) tarafından yapılan ailesel mutluğun ve iyimserliğin çocukların davranışlarını olumlu yönde etkilediği, çocukların problem davranışlarıyla ailesel stres arasında önemli bir ilişki olduğu ve problem davranışlar karsısında çocuğun tutumunun ebeveynine benzer olduğu saptanmıştır. Yine yapılan birçok araştırmada aile işlevleriyle çocuklarda görülen davranış problemleri arasında ilişki olduğu tespit edilmiştir (Avc1, 2006). Sonuç olarak bu ve benzeri çalışmalarda üstün zekâlı, normal zekâ düzeyine sahip ve zihinsel engelli öğrenciler arasında, aile işlevlerinin sağlıklı olup olmayışı ve çocukların davranış problemleri açısından çeşitli farklılıklar bulgulanmıștır. Aynı zamanda öğrencilerin aile işlevleri ile davranış problemleri arasında yordayıcı anlamlı ilişkiler olduğu görülmüştür. Bu sebeple anne-babalar kendini geliştirmeli, aile içerisinde sağlıklı ilişkiler ağı kurabilmeli ve aile yaşamlarının daha nitelikli olabilmesi için çocuklarının gelişim özelliklerine karşı duyarlı davranıp ihtiyaç duydukları yardımları uzmanlara başvurarak alabilmelidir.

\section{Kaynaklar}

Avc1, R. (2006). Şiddet davranışı gösteren ve göstermeyen ergenlerin ailelerinin aile işlevleri, öfke ve öfke ifade tarzları açısından incelenmesi. (Yayınlanmamış Yüksek Lisans Tezi). Çukurova Üniversitesi, Adana.

Baker, B. L., Blacherj. J. \& Olsson, M.B. (2005). Pre-school children with and without developmentaal delay: behaviour problems parents' optimism and well-being. Journal of Entellectual Disability Research, 49 (8), 575-590

Başbakanlık Aile Araştırma Kurumu Başkanlığı, (1998). Aile içinde ve toplumsal alanda şiddet. Ankara: Yayın No:113.

Bosco, G. L., Renk, K., Dinger, T.M., Epstein, M. K. \& Phares, V. (2003). The connections among adolescents' perceptions of parents, parental psychological symptoms, and adolescent functioning. Journal of Applied Developmental Psychology, 24 (2), 179-200.

Bulut, I. (1990). Aile değerlendirme ölçeği el kitabı. Ankara: Özgüzeliş Matbaası.

Büküşoğlu, N., Aysan, F. ve Erermiş, S. (2001). Okul fobisi olan çocukların davranışsal özellikleri, annelerinin ruhsal belirti düzeyleri ve aile fonksiyonlarının incelenmesi. Ege Tip Dergisi, 40(2), 99 - 104.

Büyüköztürk, Ş., Kılıç-Çakmak, E., Akgün, Ö. E., Karadeniz, Ş. ve Demirel, F. (2012). Bilimsel Araştırma Yöntemleri. Ankara: Pegem Akademi.

Chandler, K.L. (2015). Recommendations for practice: designing curriculum for gifted students. Turkish Journal of Giftedness and Education, 5(2), 157-166. 
Clark, B. (2015). Üstün zekâlı olarak büyümek. Evde ve okulda çocukların potansiyellerini geliştirmek. (Çev. F. Kaya ve Ü. Oğurlu). İstanbul: Nobel Akademik Yayıncilık.

Cornell, D. G., \& Grossberg, I. N. (1989). Parent use of the term "gifted": Correlates with family environment and child adjustment. Journal for the Education of the Gifted, 12(3), 218-230.

Çiçekci, A.(2000).10-15 Yaş grubundaki engelli bireyler ile engelli olmayan bireylerin davranıs problemlerinin karşılaştırmalı olarak incelenmesi. Yüksek Lisans Tezi, Ankara Üniversitesi, Ankara

Eripek, S. (2011). Zekâ geriliği olan çocuklar. A. Ataman (Ed.), Özel eğitime giriş içinde (s.153-171). Ankara: Gündüz Eğitim ve Yayıncılık.

Eripek, S. ve Vuran, S. (2009), Zihinsel yetersizliği olan çocukların eğitimi. G. Akçamete (Ed.), Özel Eğitim içinde (s.243-278). Ankara: Kök Yayıncılık.

Eryılmaz, A. (2010). Aile yapısı ergeni mutlu eder mi?. Bilim, Kültür ve Araştırma Dergisi, 6(22), 21-30.

Fonseca, C. (2011). Emotional intensity in gifted students: Helping kids cope with explosive feelings. Waco, TX: Prufrock Press, Inc.

Freitas, F.M. L. P. D., Del Prette, A., \& Del Prette, Z. A. P. (2014). Social skills of gifted and talented children. Estudos de Psicologia, 19(4), 288-295.

Gander, M.J. ve Gardiner, H.W. (2007). Çocuk ve ergen gelişimi. (B. Onur, Haz.), Ankara: İmge Kitapevi.

Halversen, H. (2016). The implemetation of interventions for problem behaviour based on the results of precursor functional analyses in the early childhood, Setting Utah State University.

İkiz, F. E., Mete-Otlu, B. ve Ekinci-Vural, D. (Aralık, 2016). Erken çocukluk döneminde görülen problem davranışlar: öğretmenlerin değerlendirmesi. Sosyal Bilimler Enstitüsü Dergisi, 8(17), 216-229.

Kaner, S. ve Çiçekçi, A.(2000). Gözden geçirilmiş davranış problemleri kontrol listesinin Türkçeye uyarlanması. Özel Eğitim Dergisi, 2(14), 23-34

Leana-Taş̧̧ılar, Z.M. ve Kanlı, E.(2014). Üstün Zekâlı ve Normal Gelişim Gösteren Çocukların Mükemmeliyetçilik ve Öz-Sayg1 Düzeylerinin İncelenmesi. Ankara Üniversitesi Eğitim Bilimleri Fakültesi Dergisi,47(2), 1-20.

Lee,S.Y.,Olszewski-Kubilius,P., \& Thomson,D. (2012). Academically gifted students' perceived interpersonal competence and peer relationships. Gifted Child Quarterly,56, 90-104.

Mash, E. J., \& Barkley, R. A. (2014). Child psychopathology. Guilford Publications.

May, E.M \& Kennedy, C.H.(2010). Health and problem behavior among people with intellectual disabilities. Association for Behavior Analysis İnternational, 3(2), 4-12.

Morawska, A. \& Sanders, M.R. (2009). Parenting gifted and talented children:conceptual and empirical foundation. Gifted Child Quarterly.53(3), 163-173.

Nail, J.M. \& Evans, J.G. (1997). The emotional adjustment of gifted adolescents: A view of global functioning. Roeper Review, 20(1), 18-21.

Navaro, L. (2001). Beni Duyuyor musun?. İstanbul: Yapa Yayınları

Neihart, M (1999). Impact of giftedness on psychological well-being. Roeper Review, 22, (1), 123-127.

Prinzie, P., Onghena, P., Hellinckx, W., Grietens, H., Ghesoquiere, P. \& Colphin, H. ( 2004). Parents and child personality characteristics as predictors of negatif discipline and externalizing problem behavior in children. European Journal of Personality, 18, 73 - 102.

Sak, U. (2014). Üstün zekâlılar, özellikleri, tanılanmaları, eğitimleri. Ankara: Vize Yayınevi.

Savi, F. (2008). 12-15 yaş arası ilköğretim öğrencilerinin davranış sorunları ile aile işlevleri ve anne-baba kişilik özellikleri arasındaki ilişkisinin incelenmesi, Doktora Tezi, Dokuz Eylül Üniversitesi, İzmir. 
Smith, J. D., Dishion, T.J., Shaw, D. S., Wilson, M.N., Winter, C. C., Patterson, G.R. (2014). Coercive Family Process And Early Onset Conduct Problems From Age 2 To School Entry. Development and Psychopathology, 26 (401), 917-932.

Sözügeçer, Z. (2011). Çocuklardaki davranış problemlerinin, bağlanma stilleri, aile işlevleri ve anne kabul algıları açısından incelenmesi, Yüksek Lisans Tezi, İstanbul Üniversitesi, İstanbul.

Sternberg, R. J. (2000). The theory of successful intelligence. Gifted education international, 15(1), 4-21.

Tabak, N. (2007). İlköğretim birinci kademede davranışsorunları olan çocukların anne-baba tutumları. Yüksek Lisans Tezi, Kocatepe Üniversitesi, Afyon.

Volkmar, F.R, \& Dykens, E. (2002). Mental retardation. İn M. Rutter \& E. Taylor (Eds.), Child and adolescent psychiatry (pp. 697-720). Massachusetts: Blackwell Publishing Company.

Yavuzer, H. (2012). Çocuk psikolojisi. İstanbul: Remzi Kitabevi.

Yee Lim \& M.S. Wong C.P. (2009). Impact of cerebral palsy on the quality of life in patients and their families. Neurology Asia, (14), 27-33.

Yıldırım, A. ve Şimşek, H.(2013). Sosyal bilimlerde nitel araştırma yöntemleri. Ankara: Seçkin Yayıncılık.

Yıldırım, Y. (2016). Eğitim sosyolojisi perspektifi ile Piaget ve Vygotsky’nin bilişsel gelişim kuramları üzerine sosyolojik bir analiz denemesi. Bartın Üniversitesi Eğitim Fakültesi Dergisi, 5(2), 617-628. 